\title{
BALD EAGLE MIGRATION IN SOUTHEASTERN MANITOBA
}

RUDOLF F. KOES, 135 Rossmere Crescent, Winnipeg, Manitoba, R2K 0G1 and PETER TAYLOR, P.O. Box 597, Pinawa, Manitoba. R0E 1 L0

Gerard and Hatch recently described the migration of the Bald Eagle through southern Saskatchewan and Manitoba, and North Dakota. ${ }^{1}$ They appear to understate the importance of migration routes in southeastern Manitoba, especially with regard to spring migration along the Red River, and fall concentrations on or near southern Lake Winnipeg. We believe the following notes will shed more light on this subject.

Table 1 lists daily counts of five or more Bald Eagles in southeastern Manitoba, during spring and fall migrations between 1978 and 1983, inclusive. This should be regarded as a representative sample, since it includes only those records which are readily at hand to us. Eagles and various other diurnal raptors make extensive use of thermals rising from the wooded banks of the Red River, especially in springs when snow still covers the ground in late March and early April.

The records at St. Adolphe (on the Red River about $12 \mathrm{~km}$ south of Winnipeg) present a different picture from Shortt's observations in Winnipeg, as cited by Gerrard and Hatch -14 Bald Eagles in 2 days of observation in one spring, as opposed to 6 sightings in 50 years. From personal observation, Koes has found that large numbers of raptors bypass Winnipeg by following the La Salle River upstream or, especially in the case of Bald Eagles, by following the Red River Floodway in a northeasterly direction around the city. As St. Adolphe is not continually manned by birders, the total number of eagles passing by is not known. The highest count was nine on 15 April
1979; more typically, two or three birds will come over during the few hours of observation.

Gerrard and Hatch refer briefly to a large spring movement through Whiteshell Provincial Park; the large triangular symbol in their Fig. 2 corresponds to the 20 April 1982 record in Table 1. The high counts on the Rennie River appear to be local concentrations of birds in the course of migration along the Winnipeg River system. A few Bald Eagles are almost invariably seen on birding outings along the Winnipeg River in late March and April.

The Allegra and River Hills records are interesting, since they involve small concentrations of Bald Eagles several $\mathrm{km}$ from major wterways. On 8 April 1978 Taylor and Reto Zach saw an adult and a subadult bird migrating northward along the boundary between forest and farmland, alongside a low glacial beach ridge near Allegra. Three subadult birds were resting in a stubble field nearby. It was an overcast day, with a blustery southwest wind. The slight topographic relief of the beach ridge, in otherwise flat territory, may have attracted the eagles to this route, which lies about $6 \mathrm{~km}$ east of the Brokenhead River, and $20 \mathrm{~km}$ west of the Winnipeg River. The six birds seen by Taylor near River Hills on 3 April 1983 had clearly been attracted by offal in a field, some $7 \mathrm{~km}$ south of the Winnipeg River, and $3 \mathrm{~km}$ east of the much smaller Whitemouth River. Up to four Bald Eagles have been seen at the same locality in other springs.

Figure 3 of Gerrard and Hatch indi- 
Table 1. RECORDS OF FIVE OR MORE BALD EAGLES PER DAY DURING MIGRATION IN SOUTHEASTERN MANITOBA, 1978-83.

Location

Allegra

Rennie River

St. Adolphe

St. Adolphe

Oak Hammock Marsh

Oak Hammock Marsh

Hecla Island Provincial

Park

Victoria Beach

Patricia Beach

Patricia Beach to

Grand Beach

Rennie River

Seven Sisters to

Victoria Beach

Hecla Island Provincial

Park

Patricia Beach to

Victoria Beach

River Hills

Patricia Beach and

Beaconia

Hecla Island Provincial

Park

Lac du Bonnet

Patricia Beach to

Grand Beach

Oak Hammock Marsh

$\begin{array}{ll}\text { Date } & \text { Numb } \\ 08 / 04 / 1978 & 1 \mathrm{a}, 4 \mathrm{i} \\ 21 / 04 / 1978 & 12 \mathrm{u} \\ 31 / 03 / 1979 & 3 \mathrm{a}, 2 \mathrm{i} \\ & \\ 15 / 04 / 1979 & 1 \mathrm{a}, 8 \mathrm{i} \\ 18 / 11 / 1979 & 3 \mathrm{a}, 3 \mathrm{i} \\ & \\ 25 / 11 / 1979 & 2 \mathrm{a}, 6 \mathrm{i} \\ & \\ 15 / 11 / 1980 & 4 \mathrm{a}, 3 \mathrm{i} \\ 11 / 10 / 1981 & 5 \mathrm{u} \\ 27 / 10 / 1981 & 4 \mathrm{a}, 6 \mathrm{i} \\ 01 / 11 / 1981 & 3 \mathrm{a}, 9 \mathrm{i}\end{array}$

20/04/1982 5a, 13i

$16 / 10 / 1982$

06/11/1982

$6 a, 4 i, 1 u$

$5 a$
Observers

P. Taylor, R. Zach.

M.G. Siepman.

Manitoba Naturalists Society

(M.N.S.) field party.

M.N.S. field party.

N.J. Cleveland, D.R.M. Hatch,

G.E. Holland, R.F. Koes, J. Zoch.

R.F. Koes.

M.N.S. field party.

R.F. Koes.

M.G. Siepman.

A. Blewett, N.J. Cleaveland, G.D Grieef, G.E. Holland, R.F. Koes, I.A. Ward.

D.R.M. Hatch, M.G. Siepman.

13/11/1982 3a, 2i, 1u M.N.S. field party.

03/04/1983 3a, 3i P. Taylor.

19/10/1983 5a, 15i M.G. Siepman.

25/10/1983 4a, $4 i \quad$ R. John.

02/11/1983 8a E. Kozak, D. Smith.

05/11/1983 5a, 12i M.N.S. field party.

05/11/1983 4a, 11i G.E. Holland.

${ }^{*} \mathrm{a}=$ adult, $\mathrm{i}=\mathrm{immature}$ or subadult, $\mathrm{u}=$ undetermined or unrecorded.

cates minimal fall migratory movements of Bald Eagles in southeastern Manitoba. This is at odds with our data (Table 1). Up to 20 Bald Eagles per day have been observed along the southeastern shore of Lake Winnipeg, from Patricia Beach to Victoria Beach, in October and November. Up to eight birds per day have been seen at Hecla Island; many more probably occur, since much of the area can not be surveyed satisfactorily from the ground. The 11 Bald Eagles seen on 16 October 1982 included 7 birds scattered along the Winnipeg River from Seven Sisters to the outfall in Traverse Bay, Lake Winnipeg.
Oak Hammock Marsh has harboured at least 15 Bald Eagles at one time. They are especially numerous in falls when many crippled waterfowl are present. Some of the birds seen at Hecla Island and along the Winnipeg River may have been local residents which had not yet begun to migrate, but other sightings were away from known nesting territories.

Taylor has observed single Bald Eagles migrating up the Winnipeg River near Pinawa in November, and small numbers occur there into December. There are only scattered records of migrating eagles along the Red 
River in fall. It therefore appears that the Winnipeg River is the more important route by which Bald Eagles leave southeastern Manitoba, but the gradual nature of this withdrawal makes this aspect hard to assess.
'GERRARD, J.M. and D.R.M. HATCH. 1983. Bald Eagle migration through southern Saskatchewan and Manitoba and North Dakota. Blue Jay 41:146-154.

\section{HUMMINGBIRDS AT ITUNA, SASKATCHEWAN}

MARY F. BRENNAN, Box 104, Ituna, Saskatchewan. SOA 1 NO

My brother, Tom Yates and his neighbour put up feeders for the hummingbirds in Ituna. In July 1983 Tom discovered a hummingbird's nest in his front yard. It was situated on a horizontal branch of a black poplar tree just at eye level, and from the front was completely concealed by a large overhanging leaf.
On the outside the nest was covered with tiny flakes of grey lichen and it was lined with soft white cotton from some flower seed heads. The whole would have fit into an egg cup. The photograph of the nest was taken 11 July 1983. At that time there were 2 tiny white eggs in it about the size of small white beans, which soon hatched into

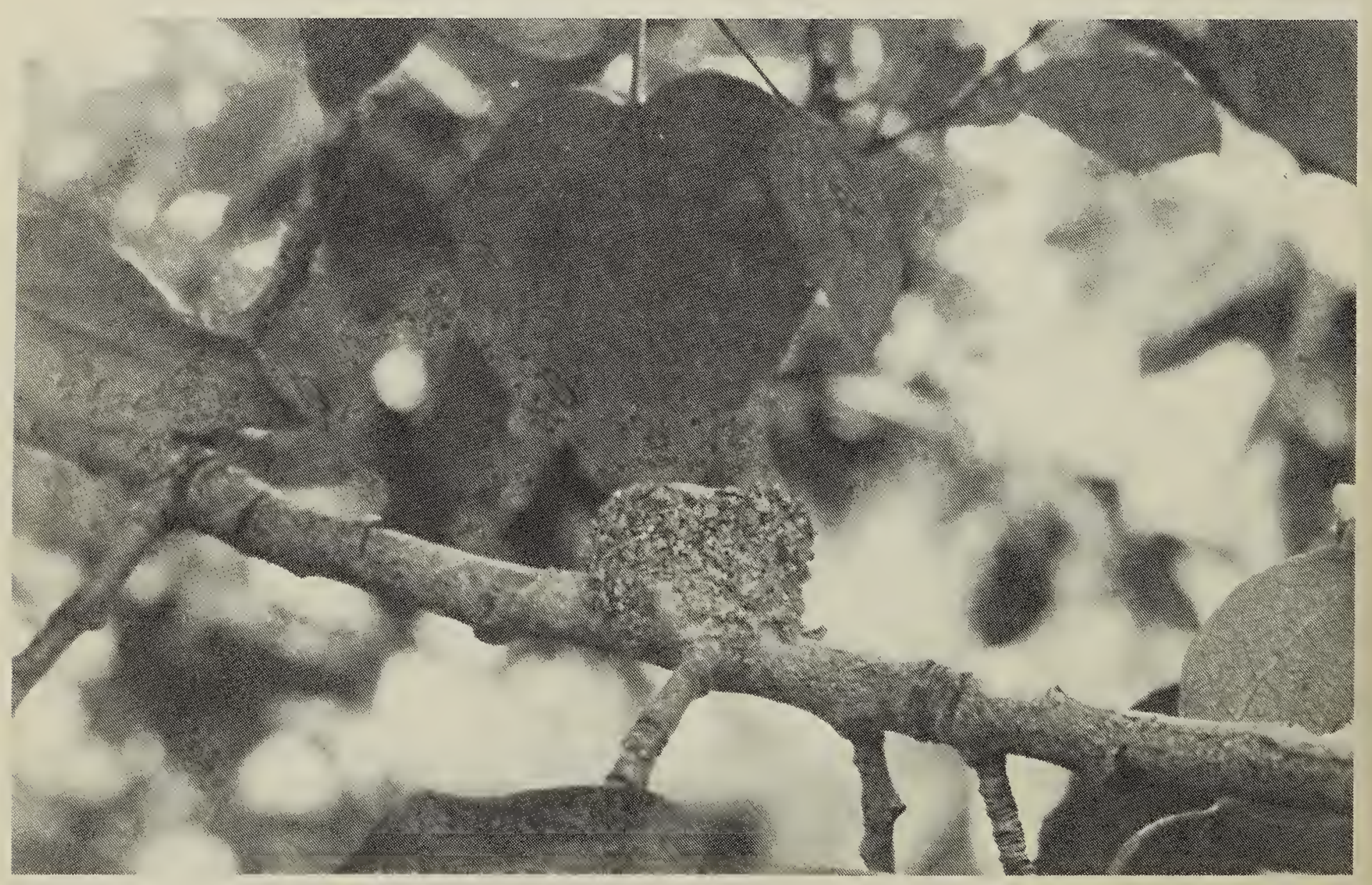

